\title{
Effects of Training on Employee Performance in Telecommunication Industry of Nepal
}

\author{
Laxman Raj Kandel \\ Lecturer, Nepal Commerce Campus, T.U. \\ Kadellaxman1@gmail.com
}

\begin{abstract}
Employees are major assets of any organization. The vigorous role they play towards a company's accomplishment cannot be undervalued. As a result, preparing these unique resources through effective training becomes authoritative so as to use the job performance. Also position them to require on the challenges of the today's competitive business environment. Though general research has been shown within the area of human research management, the similar cannot be said on employee training specifically because it concerns developing nations.
\end{abstract}

The purpose of this study was to gauge the consequences of training on employee performance, using the telecommunication industry in Nepal. So as to grasp the study aim, four goals were developed and these focused particularly on identifying the training programs' current within the industry, the target of the training offered, and therefore the methods employed and lastly the results of training and development on human resource performance.

The study was supported two case studies of the biggest telecommunication companies operating in Nepal. A qualitative research approach of the facts collection was approved using a questionnaire including of 18 questions dispersed to 240 respondents. Supported this sample the results found, show that training features a clear effect on the performance of employees. The findings can prove useful to human resource managers, human resource policy decision makers, still as government and academic institutions.

Keywords: Training, Performance, Effects, Telecommunication, Employee

\section{Introduction}

There is no doubt that organizations worldwide are striving for success and competing in the same industry. Organizations are facing increased competition due to globalization, changes in technology, political and economic environments (Evans, Pucik \& Barsoux, 2002) and so prompting these organizations to train their employees united of the ways to arrange them to regulate to the increases above and thus enhance their performance. In every organizations responsibility to reinforce the job performance of the employees and definitely implementation of training and development is one amongst the most important steps that the majority companies must achieve this.

As is obvious that employees are a vital resource, it's important to optimize the contribution of employees to the company aims and goals as methods of sustaining effective performance. This therefore 
calls for necessitate managers to conform an adequate supply of staff that's technically and socially competent and capable of career development into specialist departments or management positions (Afshan, Sobia, Kamran \& Nasir, 2012).

In spite of the cumulative special effects on training of institutional workers by institutions, there's still inadequate literature on human resource development matters in developing countries (Debrah \& Ofori, 2006) and increasing concerns from organizational customers towards low caliber services in the telecommunications industry. It's further worth noticing that while much is understood about the economics of training in the developed world, studies of issues related to training in less-developed countries are rarely found. The current studies during this relation (Harvey, 2002; Harvey, Matt \& Milord, 2002; Jackson, 2002; amoche, 2002; Kamoche, Debrah, Hortwiz \& Muuka, 2004; Kraak, 2005) have occupied a broad-spectrum human resource management (HRM) effort generating a spot on issues like the effect of training on employee performance. This study is contributing in minimizing this gap in the literature and thereby establishes premise to understanding of some aspects of human resource management generally and training particularly in Nepal. The research issues are types of training programs exist, objectives of training, training methods used, and employee performance affect by training.

In light of the above background, the aim of the study is to look at the results of training on employee performance within the telecommunication industry in Nepal.

\section{Literature Review}

Human resource management is that the way organizations manage their staff and help them to develop (McCourt \& Derek, 2003) so as to be able to execute organizations' missions and goals successfully. Briscoe's (1995) core HRM functions namely staffing, training and development, performance appraisal, compensation and benefits, and at last union and employee relations and health and safety.

Human resource development is the amalgamation of individual, career and organization development roles thus as to achieve maximum productivity, quality, opportunity and contentment of organizations associates as they work to accomplish the goals of the organization (Pace, Phillip, \& Gordon, 1991).

Afshan et al. (2012) express performance for the reason that the accomplishment of explicit tasks measured against scheduled or identified standards of accurateness, completeness, cost and speed. Employee performance might be exhibited in upgrading in production, easiness in using the latest technology, exceedingly motivated workers.

\section{Training and Development}

Training and development drips under HRD drive which has been argued to be a significant function of HRM (Weil \& Woodall, 2005).

Training is also a variety of activity which is planned, systematic and it ends up in enhanced level of skill, knowledge and competency that are necessary to perform work effectively (Gordon, 1992).

Development is also comprehensive and enduring multi-faceted set of activities (training activities among them) aimed at delivering somebody or a company up to a different threshold of performance, frequently to perform some job or a replacement role within the future (McNamara, 2008).

As one of the key functions within HRM, training has for elongated been renowned and thus enticed inordinate research attention by academic writers (Gordon, 1992; Beardwell, Holden \& Claydon, 2004). This has yielded into a spread of definitions of training. For instance, Gordon (1992) defines training as the planned and systematic modification of behavior through learning events, activities and programs which lead to the participants achieving the levels of knowledge, skills, competencies and talents to hold out their work effectively.

Guest (1987) argues that policies are necessary to make sure that employee performance is evaluated, which successively ensures that the acceptable training and development happen. With the 
assistance of the performance appraisal reports and findings, the organization is often ready to identify development needs. However, individuals themselves can help to point the areas requiring improvement as a result of the problems raised within the performance appraisal process and their career path needs.

\section{HR training needs}

Agreeing to Wognum (2001), training and development needs might happen at three organizational stages that is to say: strategic level, tactical level and operational level. so as to enable an organization formulate human resource training and development goals that is enable both formal and informal human resource training and development methods and programs create a workforce that enables effectiveness and competitiveness, it's worth giving consideration to, providing proper coordination furthermore as proper incorporation of the needs within the three levels.

The first issue is to spot the wants relevant to the organizations objectives. Consistent with Wognum (2001) and Torrington et al. (2005), there are threetypes of categorizing training and development needs. These include: resolving problems, improving certain working practices and changing or renewing the organization situation, which can arise due to innovations or changes in strategy. Further still, the training program, content and therefore the trainees' chosen rely on the objectives of the training program (Milkovic \& Bordereau ,2003).

Employee performance is frequently tested out in relations of outcomes. However, it may also be checked out in terms of behavior (Armstrong, 1995). Kenney et al. (1992) identified that employee's performance is dignified against the performance standards established by the organization. There is variety of measures that which can be taken into consideration when measuring performance for instance using of productivity, efficiency, efficacy, superiority and profitability measures (Ahuja, 2006) as briefly explained hereafter. It's gradually accomplishing superior goods and services at a progressively additional reasonable price (Stoner et al., 2009).

Several studies ensure continued by inspecting performance in terms of employee performance mostly (Purcell, Kinnie \& Hutchinson, 2003; Harrison, 2000) whereas others have prolonged to an overall outlook of organizational performance (Guest, 1997; Swart et al., 2005). In a way or another, the two are related within the sense that employee performance could be a function of organizational performance since employee performance influences general organizational performance. In respect to above, Wright \& Geroy (2001) note that employee competencies change through effective training programs. It therefore not only improves the performance of the staff to effectively perform their current jobs but also enhances the knowledge, skills an attitude of the workers necessary for the long run job, thus contributing to superior organizational performance.

According to Wright \& Geroy (2001), employee capabilities enhance through in effect training programs. It not only improves the performance of the workers to effectively perform the present job but also enhance the knowledge, skills and attitude of the workers necessary for the longer term job, thus contributing to superior organizational performance. Through training the worker competencies are developed and enable them to implement the job related work efficiently, and achieve firm objectives in a very competitive manner. Further still, dissatisfaction complaints, absenteeism and turnover will be greatly reduced when employees are so well trained that may experience the direct satisfaction related to the sense of accomplishment and knowledge that they're developing their inherent capabi lities (Pigors \& Myers, 1989).

\section{Methodology}

In this research presents a description of the methodology that's employed within the study. It spells out the techniques and methods of sampling, data collection, processing, analysis, and therefore the area within which the study is applied.

There are different types of research methods that might be used when doing research. The 
approaches consist of: qualitative research, quantitative research, and a combination of both qualitative and quantitative research. The difference between qualitative and quantitative approach arises from their procedures (Ghauri \& Grönhaug, 2005).

\section{Results}

The data is represented in arrangement of Tables and Charts. Presentation of results has been prepared in accordance by way of the study objectives.

\section{Respondents as per case company}

Table 1

Respondents as per case company

\begin{tabular}{lcc}
\hline Company & Frequency & Valid\% \\
\hline NTC & 140 & 58.33 \\
NCELL & 100 & 41.67 \\
Total & 240 & 100 \\
\hline
\end{tabular}

Source: Opinion survey, 2020

From the 240 respondents $58.33 \%$ were from NTC and $41.67 \%$ were from NCELL as shown in Table 1 above.

\section{Period of employment with company}

Table 2

Period of employment with company

\begin{tabular}{lcc}
\hline Year & Frequency & Valid\% \\
\hline $1-10$ & 122 & 50.8 \\
$11-20$ & 76 & 31.7 \\
$21-30$ & 30 & 12.5 \\
Above 31 & 12 & 5.0 \\
Total & 240 & 100 \\
\hline
\end{tabular}

Source: Opinion survey, 2020

As illustrated in Table 2 above, it is evident that over $50.8 \%$ of the respondents have worked for the companies for 1 to 10 years, $31.7 \%$ of the entire population have worked for the case companies for 11 to 20 years of age, $12.5 \%$ have worked for 21 to 30 years of age and the remaining $5 \%$ have worked for these companies for over 31 years. These consequences specify that the case companies have decent employee retention systems. The results also indicate that these employees necessitate continual training and development programs to retain them updated through their skills as well as the company progresses, for example, technological and customer associated developments so as to increase their performance.

\section{Respondent's participation in training}

Table 3

Respondent's participation in training

\begin{tabular}{lcc}
\hline Response & Frequency & $\%$ \\
\hline Yes & 174 & 72.5 \\
No & 66 & 27.5 \\
Total & 240 & 100 \\
\hline
\end{tabular}

Source: Opinion survey, 2020 
The results in the table 3 show that 174 respondents representing a $72.5 \%$ have undergone training with the respective case companies. The residual 66 , representing a $27.5 \%$, show that they have not gone over some kind of training by the company for which they effort for. This suggests that the case corporations do not aim training for all corporation employees but maybe for specific employees. Otherwise, it might be so that training is directed for particular employees from specific task-related job training.

\section{Selection for training}

Table 4

Selection for training

\begin{tabular}{lcc}
\hline Criteria & Frequency & Valid\% \\
\hline On joining the company & 80 & 33.3 \\
Supervisor's recommendation & 32 & 13.3 \\
Compulsory for all employees & 68 & 28.3 \\
Upon employee request & 12 & 5 \\
Performance appraisal & 8 & 3.3 \\
Don't know & 40 & 16.7 \\
Total & 240 & 100 \\
\hline
\end{tabular}

Source: Opinion survey, 2020

Table 4 above illustrates the results from the question about how the respondents were selected for training in their companies of work. The outcomes indicate unexpectedly that a great number of these respondents were nominated to participate and, thus, obtain training on joining the organization. This proportion of respondents is represented by $33.3 \%$. As would be expected in many cases, 68 respondents were selected for training under the criteria of all employees going through the training and this is represents by a $28.3 \%$. It is still amazing that though other employees were nominated based on their supervisors reference (32 respondents representative a 13.3\%), upon their personal demand to get training (12 respondents representing 5\%), a big number of the response rate came from the respondents who were not aware $(16.7 \%)$ of why they were selected for training. This denotes that the training method working is only implicit by the superiors' sendoff the trainees ignorant of the whole training process.

\section{Methods of facilitation at the training}

Table 5

Methods of facilitation at the training

\begin{tabular}{lcc}
\hline Facilitation method & Frequency & Valid\% \\
\hline Lecture & 8 & 3.3 \\
\hline Demonstration & 42 & 17.5 \\
Discussion & 80 & 33.3 \\
Presentation & 80 & 33.3 \\
Seminar & 30 & 12.5 \\
Total & 240 & 100 \\
\hline
\end{tabular}

Source: Opinion survey, 2020

A number of methods of facilitation that are comely employed during training are presented in Table 5 above. These are significant in understanding the dissimilar ways trainees obtain training under 
the both the on-the-job and off-the-job training technique categorizations. As revealed above, the most common methods of facilitation identified by the respondents as prevailing during their trainings are discussions (representing 33.3\%) and presentations (representing 33.3\%). The other methods demonstrations, seminars and lectures represent the remaining $17.5 \%, 12.5 \%$ and $3.3 \%$ respectively. These outcomes show that the case companies strongly importance debates and presentations. This might be partially explicated by the nature of the business of these two companies (being additional customers concerned with for example calls for a necessity to take on acceleration methods that seem more customers focused).

\section{Impact of training methods on skill}

Table 6

Impact of training methods on skill

\begin{tabular}{lcc}
\hline Response & Frequency & Valid\% \\
\hline Yes & 208 & 86.7 \\
No & 32 & 13.3 \\
Total & 240 & 100 \\
\hline
\end{tabular}

Source: Opinion survey, 2020

Table 6 analyzing the responses obtained from the respondents on the impact of training methods on their skills, the findings showed that the majority of the respondents, $86.7 \%$, believed that the training approaches used through training had an influence on their skills. However, a small percentage (13.3) believed otherwise. This consequence specifies that the training approaches used during training in the case corporations obviously emphasis on specific skills and, thus, skill enlargement is emphasized.

\section{Relevance of training to respondents work}

Table 7

Relevance of training to respondents work

\begin{tabular}{lcc}
\hline Response & Frequency & Valid\% \\
\hline Not relevant at all & 0 & 0 \\
Not relevant & 0 & 0 \\
Not sure & 32 & 13.3 \\
Effective & 166 & 69.2 \\
Very effective & 42 & 17.5 \\
Total & 240 & 100 \\
\hline
\end{tabular}

Source: Opinion survey, 2020

The above table 7 reports results from the relevance of the trainings received by the respondents to their work. Mainstream of the respondents (166 representing 69.2\%) described clear efficacy of these trainings on their work. This consequence is in line through the result previous reported on the choice of respondents for training which exposed that most of these respondents were nominated on joining the companies they effort for and required training for all employees. This specifies that HRM puts a lot of importance on training that will add value to and thus applicable to the existing work for those selected for training. 
Training impact on the performance of the employees

Table 8

Training impact on the performance of the employees

\begin{tabular}{lcc}
\hline Response & Frequency & Valid\% \\
\hline Yes & 222 & 92.5 \\
No & 18 & 7.5 \\
Total & 240 & 100 \\
\hline
\end{tabular}

Source: Opinion survey, 2020

The responses in table 8 above were collected on the impact of training on the performance of the respondents from the case companies. The correlation is measured related as it is the focus of this study. The results clearly indicate that 222 respondents representing a great percentage of $92.5 \%$ link training to their improved performance. This consequence is in stripe with prior literature which presents that training influences employee performance partially through refining employee skills which empowers them know and perform their jobs well (Wright \& Geroy, 2001; Swart et al., 2005; Harrison, 2000).

\section{Need for further training}

Table 9

Need for further training

\begin{tabular}{lcc}
\hline Response & Frequency & Valid\% \\
\hline Yes & 198 & 82.5 \\
No & 42 & 17.5 \\
Total & 240 & 100 \\
\hline
\end{tabular}

Source: Opinion survey, 2020

Table 9 was relevant to find out whether the respondents felt the need for further training. Based on the responses above, 198 respondents representing $82.5 \%$ of entire sample revealed a need for further training. Mainstream of these showed that based on the nature of their jobs in specific and corporation businesses in overall, there is forever changing technology which presents always changing customer demands for which they have to cope with. This in their judgment demands for numerous training so as to retain up-to-date in all circumstances.

\section{Conclusion}

The importance of training and development within the corporate world has been highlighted in the previous literature. Thus, it's essential to look at any issues associated with training and development in any sector of business. The aim of this study is to look at the results of training on employee performance within the telecommunications industry in Nepal. The sample of the study relies on the two biggest telecommunication companies operating in Nepal.

The findings reported during this study suggest that training and development have a bearing on the performance of employees with regards to their jobs. This result's broadly according to prior management literature on training and development. So as to realize more specific knowledge of training and development from the sample companies, different questions are presented to the respondents and thus examined. These questions are specializing in on employee participation in training, selection for training, methods of training and relevance of training to the work of the respondents. The results from the questions on employee participation in training and selection for training indicate that these companies have good and may be clear policies regarding training and development as most of the respondents 
indicated that they need participated in training which most of them were given opportunities to train under the compulsory practice of the organization for all employees and on joining the organization. In examining the question regarding the training program quality, the results indicate that the programs undertaken by the sample companies are relevant as considered by the respondent's opinions.

\section{References}

Ahuja, K. (2006). Personnel management (3rd Ed.). New Delhi: Kalyani publishers.

Afshan, S., Sobia, I., Kamran, A. \& Nasir, M. (2012). Impact of training on employee performance: a study of telecommunication sector in Pakistan. Interdisciplinary Journal of Contemporary Research in Business, 4 (6), 646-661.

Armstrong, M. (1995). A handbook of personnel Management Practices. London: Kogan Page Limited.

Beardwell, I., Holden, L. \& Claydon, T. (2004). Human Resource Management a Contemporary Approach (4th Ed.). Harlow. Prentice Hall.

Bohlander, G.W. \& Snell S.A. (2004). Managing Human Resources (13th Ed.). Mason, Ohio: SouthWestern Publishing Co.

Briscoe, D.R. (1995). International Human Resource Management. New Jersey: Prentice Hall.

Debrah, Y. A. \& Ofori, G. (2006). Human Resource Development of Professionals in an Emerging Economy: the Case of the Tanzanian Construction Industry. International Journal of Human Resource Management, 17 (3): 440 - 463.

Evans, P., Pucik V. \& Barsoux J.L. (2002). The Global Challenge: Framework for International Human Resource Management. Boston: McGraw-Hill.

Ghauri, P.N. \& Grönhaug, K. (2005). Research Methods in Business Studies: A Practical Guide (3rd ed.). London: Prentice Hall.

Gordon, B. ( 1992). Are Canadian firms under investing in training? Canadian Business Economics, $1(1), 25-33$.

Guest, D. E. (1987). Human resource management and industrial relations. Journal of Management Studies, 24, 503-521.

Harrison, R. ( 2000). Employee Development. Silver Lakes Pretoria: Beekman Publishing.

Harvey, M. (2002). Human Resource Management in Africa: Alice's Adventures in Wonderland. International Journal of Human Resource Management, 13 (7), 1119-1145.

Harvey, M., Myers, M. \& Novicevic, M. M. (2002). The Role of MNCs in Balancing the Human Capital "Books" between African and Developed Countries. International Journal of Human Resource Management, 13 (7), 1060-1076.

Jackson, T. (2002). Reframing human resource management in Africa: a cross-cultural perspective. International Journal of Human Resource Management, 13 (7), 998-1018.

Kamoche, K. ( 2002). Introduction: Human Resource Management in Africa. International Journal of Human Resource Management, 13 (7), 993-997.

Kamoche, K., Yaw. D., Frank, H. \& Gerry, N. M. (2004). Managing Human Resources in Africa. London: Routledge.

Kenney et al., (1992) Management Made East (1st Ed.). South Carolina: Omron Publishers.

Kraak, A. (2005). Human Resources Development and the Skills Crisis in South Africa: the Need for Multi-pronged Strategy. Journal of Education and Work, 18 (1), 57-83.

McCourt, W. \& Derek, E. ( 2003). Global Human Resource Management: Managing People in Developing and Transitional Countries. Cheltenham: Edward Elgar.

McNamara C. (2008). Employee Training and Development: Reasons and Benefits. Accessed 16/03/2009. http://www.managementhelp.org/index.html. 
Milkovic, G. \& Bordereau J. (2003). Human Resource Management. Toledo: Richard d Irwin.

Pace, W. R., Phillip, S. C. \& Gordon, M. E. (1991). Human Resource Development: The Field. New Jersey: Prentice Hall.

Pigors, P. \& Myers, A. C. (1989). Personnel Administration, A point of view and method (9th Ed.). New York: McGraw Hill Book Company.

Purcell, J., Kinnie, N., Hutchinson, S., Rayton, B.\& Swart, J. (2003). Understanding the People and Performance Link: Unlocking the Black-Box. Research Report, CIPD, London.

Stoner, J., Freeman, E. \& Gilbert, D. (2009). Management ( $6^{\text {th }}$ Ed.). London: Pearson.

Swart, J., Mann, C., Brown, S. \& Price, A. (2005). Human Resource Development: Strategy and Tactics. Oxford: Elsevier Butterworth-Heinemann Publications.

Torrington, D., Hall, L. \& Taylor, S. (2005). Human Resource Management (6th Ed.). London: Prentice Hall.

Weil, A., \& Woodall, J. (2005). HRD in France: the corporate perspective. Journal of European Industrial Training, 29 (7), 529-540.

Wognum, A. A. M. (2001). Vertical Integration of HRD Policy within Companies. Human Resource Development International, 4 (3), 407-421.

Wright, P. \& Geroy, D. G. (2001). Changing the mindset: the training myth and the need for word-class performance. International Journal of Human Resource Management, 12 (4), 586-600. 
Issue 1 May/June 2020 - 